\title{
BISNIS KULINER
}

“ RISOLES “

Makalah ini disusun untuk memenuhi final

Pada mata kuliah Kewirausahaan

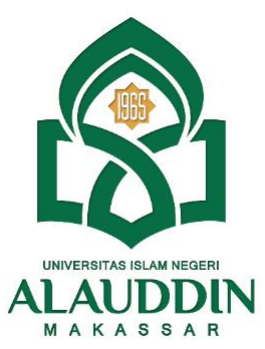

Kelompok 6 :

Gusti Yusmiana (90500120109)

Andhini Putri Novianti Nasrullah (90500120107)

Ardina Rasti (90500120106)

Ayu Puspitasari (90500120093)

Asrari (90500120124)

Dosen Pengampu :

Dra. Hj. Nuraeni Gani, MM

PERBANKAN SYARIAH

FAKULTAS EKONOMI DAN BISNIS ISLAM

UNIVERSITAS ISLAM NEGERI ALAUDDIN MAKASSAR

TAHUN 2021 


\section{KATA PENGANTAR}

Puji dan syukur kita panjatkan kehadirat Allah SWT.karena berkat rahmat dan karunia-Nya sehingga makalah yang berjudul "BISNIS KULINER RISOLES" ini dapat kami selesaikan sesuai dengan waktu yang telah ditentukan. Atas dorongan serta bimbingan yang kami terima sehingga makalah ini dapat tersusun dengan baik tanpa ada kesulitan yang berarti. Untuk itu kami mengucapkan terima kasih kepada Semua pihak yang telah membantu menyelesaikan makalah ini. Makalah ini kami buat untuk memenuhi tugas mata kuliah studi "Kewirausahaan"

Kami mengucapkan terima kasih kepada Ibu Dra. Hj. Nuraeni Gani, MM selaku Dosen Kewirausahaan program studi Perbankan Syariah. Yang telah memberikan arahan dalam menyusun makalah ini. Semoga makalah ini dapat memberikan wawasan yang lebih luas kepada pembaca.Kami menyadari bahwa makalah ini masih kurang sempurna. Oleh karena itu, kami mengharapkan kritik dan saran yang membangun dari para pembaca. Terima Kasih.

Samata-Gowa, 24 Desember 2021

Penulis 


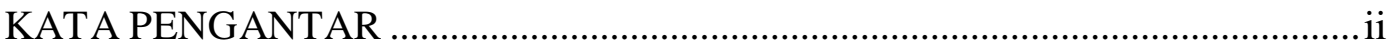

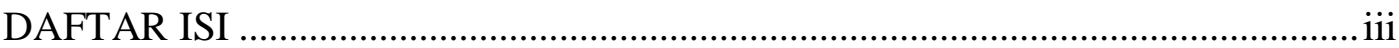

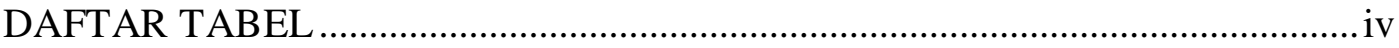

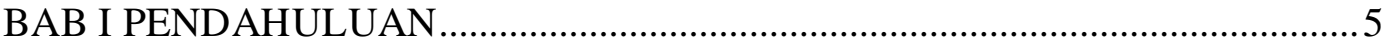

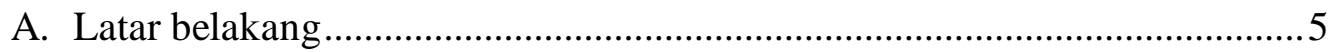

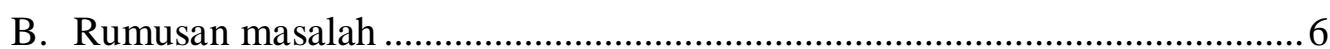

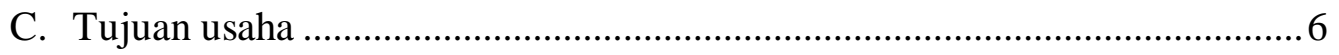

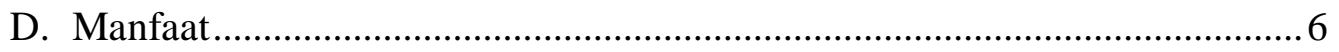

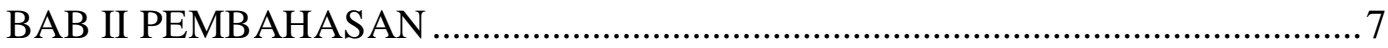

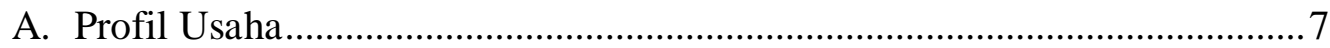

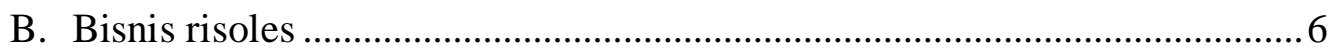

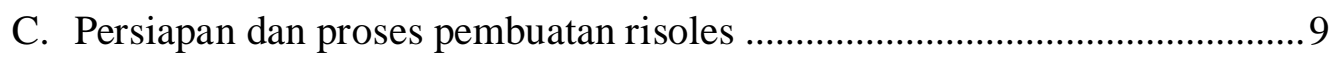

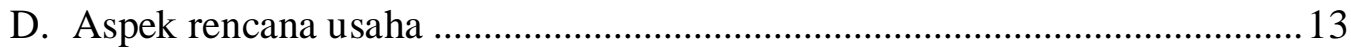

E. Strategi pemasaran produk ........................................................................... 14

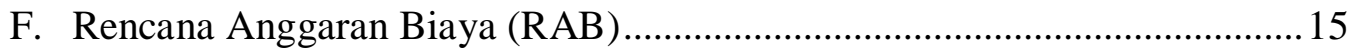

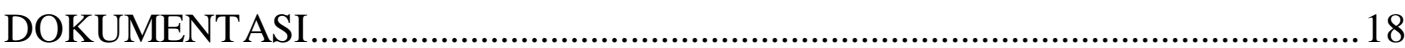

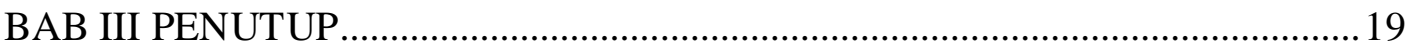

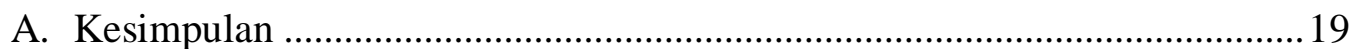

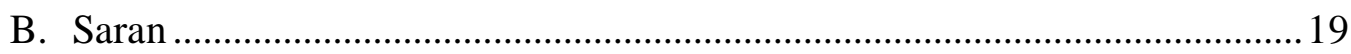

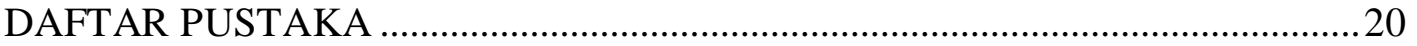




\section{DAFTAR TABEL}

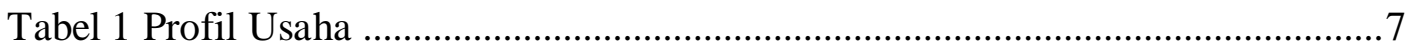

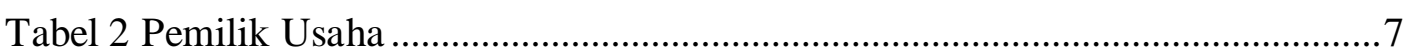

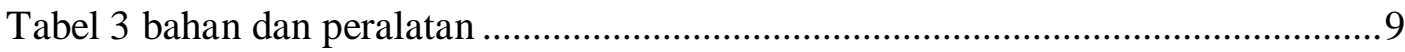

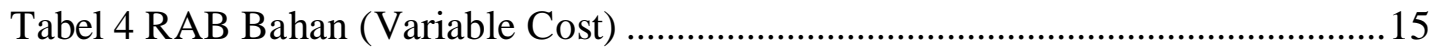

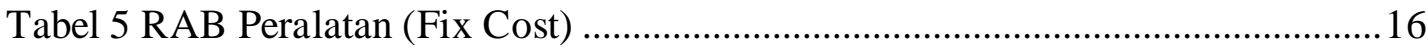




\section{BAB I}

\section{PENDAHULUAN}

\section{A. Latar Belakang}

Kewirausahaan merupakan seseorang yang memiliki kemampuan melihat dan menilai kesempatan bisnis dan berani mengambil resiko yang diperlukan untuk mengorganisasikan dan mengelola suatu bisnis dan orang yang memiliki kemampuan untuk melakukan koordinasi, wirausaha memiliki pengetahuan yang luas tentang lingkungan dan membuat keputusan-keputusan tentang lingkungan usaha mengelola sejumlah modal dan menghadapi ketidakpastian untuk meraih keuntungan.

Kewirausahaan adalah suatu keberanian untuk melakukan usaha-usaha yang dilakukan oleh seseorang atas dasar kemampuan dengan cara memanfaatkan segala potensi yang dimiliki untuk menghasilkan sesuatu yang bermanfaat bagi dirinya dan orang lain yang dibangun berdasarkan inovasi untuk menghasilkan sesuatu yang baru, memiliki nilai tambah, memberi manfaat, meciptakan lapangan kerja dan hasilnya berguna untuk orang lain.

Menjalankan suatu usaha dibidang-bidang kuliner atau jajanan pasar khas Indonesia merupakan enis usaha yang berkelanjutan. Dalam kehidupan seharihari masyarakat indonesi tidak lepas dengan makanan gorengan yang menjadi cemilan favorit. Oleh karena itu, kami memilih jenis usaha "RISOLES" untuk dijual. Sebagaimana kita ketahui bahwa Risoles adalah makanan ringan yang cukup terkenal di indonesia. Peluang usaha Risoles dijadikan salah satu peluang usaha yang dapat menguntungkan dan potensi bisnisnya sangat bagus untuk digali. Bisnis seperti ini dapat dilakukan oleh semua kalangan Karena Usaha Risoles ini tidak membutuhkan modal yang besar untuk mengawalinya. 


\section{B. Rumusan Masalah}

1. Mengidentifikasi bisnis Risoles!

2. Bagaimana persiapan dan proses pembuatan Risoles ?

3. Bagaimana Aspek Rencana Usaha?

4. Bagaimana Strategi pemasaran pada usaha Bisnis Risoles!

5. Mengidentifikasi Rencana Anggaran Biaya (RAB) pada Bisnis Risoles !

\section{Tujuan Usaha}

Tujuannya adalah untuk meningkatkan ekonomi bagi penguasahanya sendiri, menjadikan contoh bagi masyarakat yang tidak memiliki keterampilan, sehigga diharapkan agar dengan adanya usaha ini baik dikalangan masyarakat ataupun lingkungan kampus, dapat memiliki pekerjanaan sendiri atau usaha sendiri walaupun dengan kemammpuan modal yang sangat terbatas. Serta untuk memenuhi kebutuhan orang-orang yang suka dengan makanan cepat saji, kini kami hadir dengan menawarkan makanan cepat saji dan memiliki kandungan serat yang baik bagi tubuh.

\section{Manfaat}

1. Menciptakan lapangan kerja sendiri

2. Sebagai media penghasil sampingan

3. Memperkenalkan makanan dari anak bangsa

4. Memenuhi keinginan masyarakat 


\section{BAB II}

\section{PEMBAHASAN}

\section{A. Profil Usaha}

Tabel 1 profil usaha

\begin{tabular}{|l|c|c|}
\hline 1. & Nama Usaha & Risoles \\
\hline 2. & Bidang Usaha & Industri Rumahan \\
\hline 3. & Jenis Produk/Jasa & Cemilan atau jajanan \\
\hline 4. & Tanggal mulai berdiri & 14 November 2021 \\
\hline
\end{tabular}

Tabel 2 pemilik usaha

\begin{tabular}{|l|c|c|}
\hline No. & Nama & Jabatan \\
\hline 1. & Gusti Yusmiana & Pemimpin \\
\hline 2. & $\begin{array}{c}\text { Andhini Putri Novianti } \\
\text { Nasrullah }\end{array}$ & Bendahara \\
\hline 3. & Ardina Rasti & Anggota \\
\hline 4. & Ayu Puspitasari & Anggota \\
\hline 5. & Asrari & Anggota \\
\hline
\end{tabular}

\section{B. Risoles}

Risoles adalah sejenis makanan cemilan atau jajanan khas Indonesia. Risoles dalam bahasa Belanda disebut Rissole, yaitu pastri yang berisi daging atau sosis, serta sayur-sayuran yang digulung dadar kemudian diberi lapisan tepung lalu digoreng hingga kecoklatan. Isian dalam risoles tersebut bisa berupa daging cincang, sosis, telur, ataupun

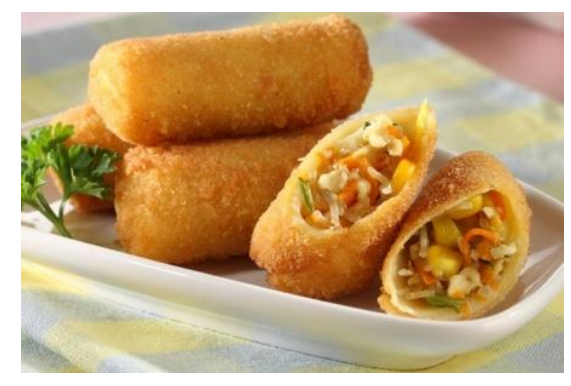
udang, serta sayur-sayuran seperting kentang, wortel. Untuk kulit adar pada risoles dapat dibuat dari bahan-bahan seperti tepung terigu, telur, serta air. Ada dua jenis risoles yang sangat terkenal dindonesia, yang pertama yaitu risoles dengan isian sayur lalu dicampur dengan daging cincang, dan yang kesdua yaitu 
risoles dengan isian potongan-potongan wortel, Kentang dan sayuran lainnya dengan sosis lalu diberi toping mayo.

Risoles merupakan cemilan anak anak karena kandungan daging dan sayuran didalamnya. Apalagi tertambah sayuran khusus didalamnya yang digunakan seperti wortel yang kita ketahui bahwa, wortel bermanfaat untuk menjaga kesehatan mata dan mmpu meningkatkan proses metabolisme serta dayatahan tubuh.

Adapun manfaat dari risoles untuk kesehatan tubuh yaitu :

- Sebagai sumber energi

Risoles adalah makanan ringan yang memiliki banyak sekali kandungan nutrisi, salah satunya adalah kalori yanng cukup tinggi. Dimana kalori tersebut berperan sebagai sumber energi bagi tubuh. Maka dari itu jumlah kaori yanng dimiliki oleh makanan ini mampu untuk mencukupi kebutuhan energi harian kita yang dibutuhkan saat melakukan aktivitas dalam kehidupan sehari-hari.

- Memperkencang dan memperkuat otot

Kandungan protein memang memiliki banyak sekali manfaat untuk tubuh kia. Salah satunya juga dapat menguatkan dan mengencangkan otot. Oleh karena itu, risoles ini cocok buat orang yang ingin membentuk tubuh.

- Dapat mencegah obesitas

Risoless ini mengandung lemak yang rendah dan protein yang tinggi. Maka dari itu dapat mencegah naiknya berat badan, jadi kita tidak perlu takut berat badan naik jika mengkonsumsi makanan ini dengan banyak.

- Meningkatkan kekebalan tubuh

Kandungan nutrisi yang dimiliki risoles ini dapat meningkatkan sistem kekebalan tubuh. Karena didalamnya mengandung antioksidan yang tinggi, sehingga untuk menjaga daya tahan tubuh dari serangan penyakit. 


\section{Persiapan Dan Proses Pembuatan Risoles}

Menjual Risoles merupakan salah satu bentuk usaha dalam dunia perdagangan yang kreatif. Dengan menjual risoles yang menyediakan suatu jenis makanan yang dapat menarik perhatian pembeli, karena makanan ini mempunyai rasa yang sangat berkulitas dan dijual dengan harga yang cukup buat Mahasiswa (i).

Melihat peluang usaha risoles sangat berpotensi untuk menjadi usaha sampigan mahasiswa, karena waktu belajar tidak terhalangi dengan waktu kerja. Selain tugasnya untuk mencari ilmu bukan hanya mencari keuntungan, tetapi juga pengalaman yng memmang jika tidak di asah pada masa kuliah akan tumpul. Selain itu berwirausaa dapat menjadikan diri setiap mahasiswa menjadi pribadi yag lebih baik lagi, menjadi mandiri, dan mampu bersosialisasi dengan orang banyak. Dan yang paling penting dapat menumbuhkan jiwa kewirausahaan sebagai bekal bagi mahasiswa setelah lulus kuliah.

\section{Tabel 3 bahan dan peralatan}

\begin{tabular}{|l|l|}
\hline \multicolumn{1}{|c|}{ Bahan } & \multicolumn{1}{|c|}{ Alat } \\
\hline Bahan untuk isian risoles sosis & 1. Kompor \\
mayo & 2. Wajan \\
1. Telur & 3. Spatula \\
2. Sosis & 4. Teflon \\
3. Mayones & 5. Baskom sedang \\
4. Minyak goreng secukupnya & 6. dll. \\
Bahan untuk isian risoles sayur & \\
1. Wortel & \\
2. Kentang / Ubi & \\
3. Daun seledri \& daun bawang & \\
4. Bawang merah \& bawang & \\
5utih & \\
6. Merica & \\
7. Telur & \\
Bahan untuk kulit Risoles & \\
1. Tepung Terigu & \\
2. Garam secukupnya & \\
3. Air & \\
4. Tepung roti & \\
5. Telur &
\end{tabular}




\section{Cara membuat isian Risoles :}

1. Potong-potong wortel dan kentang.

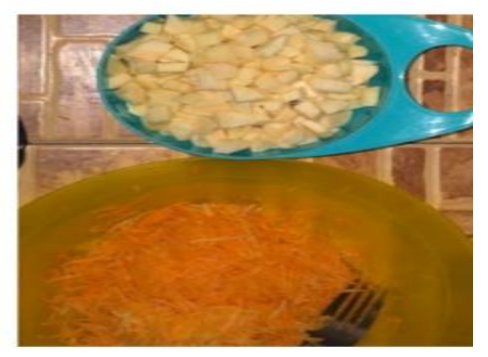

2. Cincang daun seledri dan daun bawang
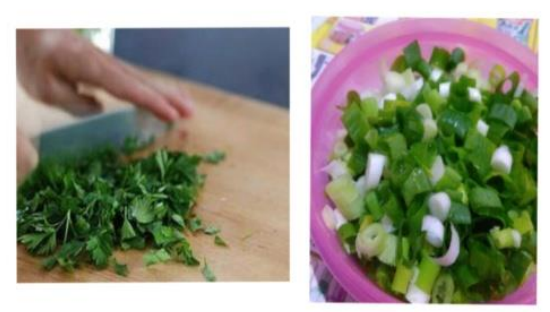

3. Untuk isian risoles masak telur hingga matang, lalu potong telur tersebut sesuai selera, begitupun dengan isian sosis.
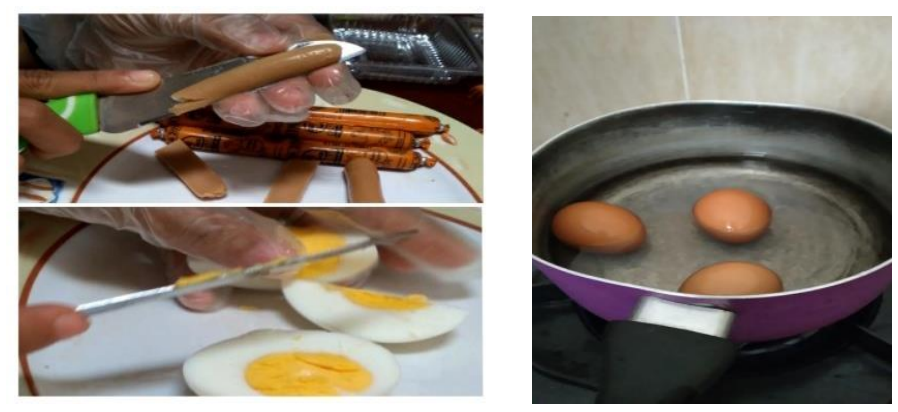

4. Haluskan bawang merah dan bawang putih lalu tumis dengan menggunakan minyak yang cukup hingga harum.

5. Tambahkan wortel dan kentang yang sudah dipotong. Lalu masukkan daun bawang \& daun seledri kedalam bumbu yang sudah diaduk merata.

6. Tuangkan penyedap rasa. jika sudah matang dan rasanya sudah pas, angkat dan sisihkan. 
$>$ Cara membuat kulit risoles :

1. Siapkan semua bahan untuk kulit risoles.

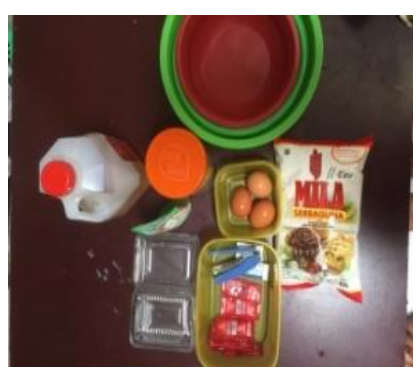

2. Campur terigu dan telur lalu tambahkan air, kemudian aduk dengan rata. Setelah itu saring adonan tersebut.
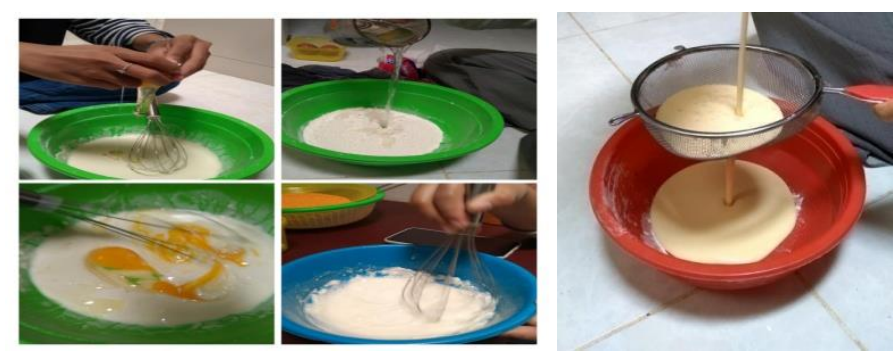

3. Panaskan teflon diatas api yang sedang, lalu tuang adonan sesuai dengan selera.
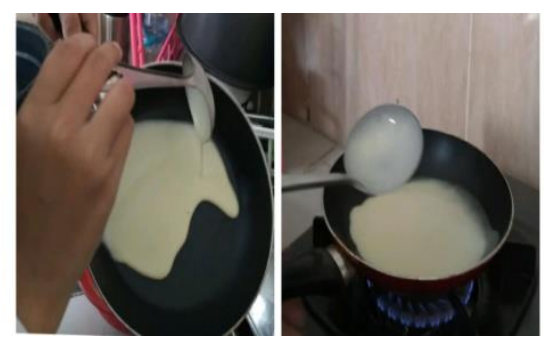

\section{Cara Membuat Risoles :}

1. Ambil satu lembar kulit dadar kemudian isi secukupnya dengan isian risoles tadi (bisa ditambahkan sosis dan telur masak didalammnya).

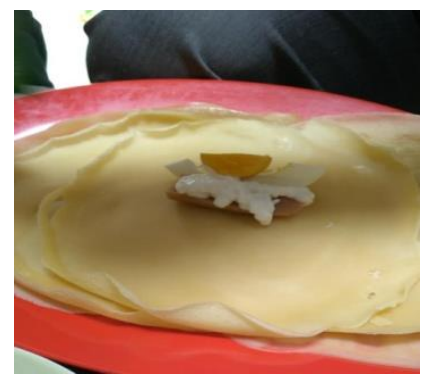


2. Gulung risoles, kemudian rekatkan kulit dadar tersebut. Lakukan hingga semua kulit dadar dan isian risoles habis.

3. Celupkan risoles tersebut kedalam tepung terigu yang telah dicairkan dan taburi tepung roti.
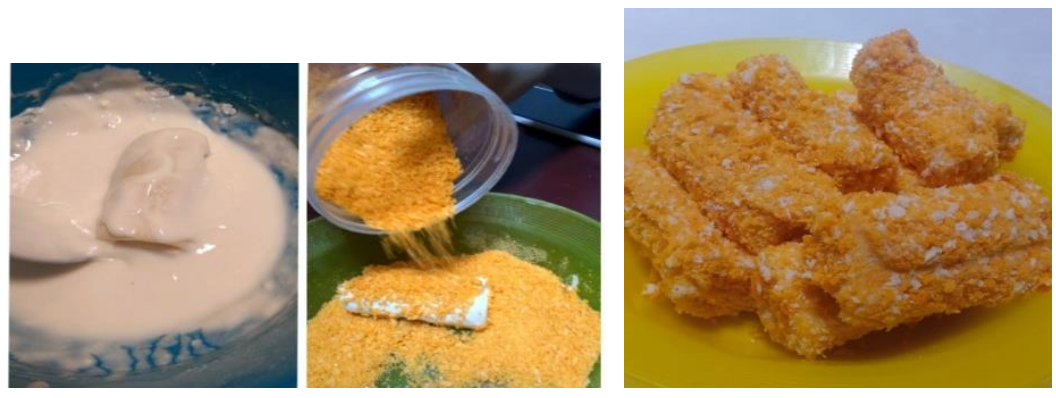

4. Setelah itu diamkan risoles beberapa menit, lalu panaskan minyak dan goreng risoles tersebut hingga matang. kemudian angkat dan tiriskan bersama dengan saus atau mayonais.

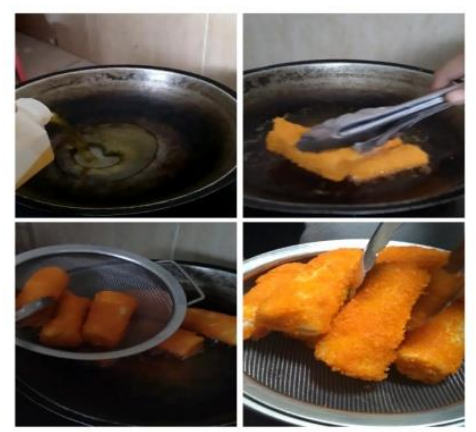

5. Kemudian angkat dan tiriskan bersama dengan saus.

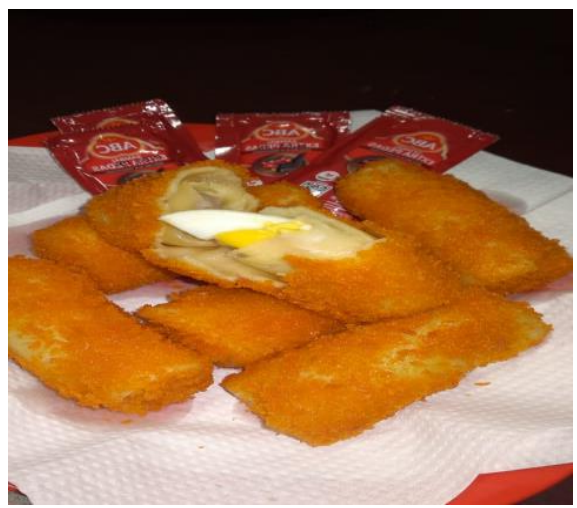




\section{Aspek Rencana Usaha}

1. Aspek Pemasaran

Dalam usaha ini produk yang dijual berupa makanan yaitu "Risoles". Yang pemasarannya disekitar wilayah Samata-Gowa, dekat dengan tempat produksi karena mempertimbangkan efisiensi. Segmen pasar yang dituju adalah semua kalangan,segala usia.

2. Aspek Ekonomi Sosial

Usaha ini sangat ekonomi, karena risoles ini dapat dikonsumsi oleh segala tingkat ekonomi. Terutama bagi mahasiswa sanngat cocok dengan harga yang tidak terlalu mahal dan pastinya bergizi.

\section{Analisis SWOT}

Sebelum memulai usahakami harus mengukur kemampuan kami terhadap lingkungan sekitar, mengingat banyak pesaing melalui analisis SWOT :

a) Strength (kekuatan)

Strength yaitu mampu melihat kedalam produk apa yang menjadi kekuatan sehingga dapat mengukur kemampuan dan potensi kita kedepannya lagi yang ada produk yang dijual.

- Dapat dibeli oleh segala kalangan baik kalangan menengah keatas ataupun menengah kebawah.

- Bahan makanan terjammin sehat dan higenis

- Kualitas risol ini terjamin halal

b) Weakness (kelemahan)

Weakness yaitu mampu melihat kelemahan yang ada dalam diri kita, dengan begitu agar kedepannya bisa meminimalkan kekurangan dengan cara mau belajar dan memperbaiki sehingga dapat mengubah kekurangan menjadi kelebihan.

- Produknya mudah ditiru

- Tidak dapat bertahan lama

- Harga bahan baku tidak menentu, bahkan cenderung naik.

c) Opportunity (peluang)

Peluang yaitu mampu melihat peluang yang ada, dengan mengasah kreatifitas.

- Proses penjualan cukup strategis 
- Fasilitas yang cukup memadai

- Makanan ini sangat disukai oleh anak-anak sampai pada orang dewasa

d) Threath (ancaman)

Banyaknya pesaing yang menjual produk yang sama dengan harga yang lebih murah dibanding risoles yang kami jual.

\section{E. Strategi Pemasaran Produk}

1. Produk

Produk yang aka dijual harus senantiasa memiliki nilai ekonomis namun tetap berkualitas tanpa mengesampingkan inovasi pada produk tersebut sehingga dapat dinikmati oleh semua orang. Lebih lagi dalam menarik pelanggang juga harus memperhatikan keunikan kemasan sehingga produk tersebut mempunyai sesutu yang dapat menarik perhatian pembeli.

2. Price (harga)

Dalam penetapan harga kebanyakan orang biasanya berlomba-lomba memberikan harga yang lebih murah namun tidak memberikan kualitas produksi yang baik. Oleh karena itu harga yang kami tetapkan berdasarkan kualitas dan varian isi yang beragam, serta menyeimbangkan dengan harga bahan isian risoles yang digunakan. Namun harga masi terjangkau agar dapat dinikmati oleh semua kalangan. Adapun harga yang kami tetapkan :

- Risoles Sayur

- Risoles Sosis mayo
(2) $\operatorname{Rp} 5.000$

(2) $\operatorname{Rp} 5.000$

3. Promotion (promosi)

Promosi adaah upaya untuk memberitahukan atau menawarkan produk atau jasa dengan tujuan menarik calon konsumen untuk membeli atau mengkonsumsinya. Adapun promosi yang kita lakukan adalah :

- OFFLINE, Pada tahap awal promosi yang bisa dilakukan adalah “ Face to Face". Maksudnya adalah dengan cara memberitahukan kepada satu orang tentang produk yang dijual kemudian tersebar kepada orang lain.

- Untuk mencakup pelanggan yang lebih banya lagi dengan cara online yaitu mengandalkan media social dengan membuat Flyer yang 
semenarik mungkin lalu disebar kemedia sosial seperti whatsaap, instagram, telegram dll. Agar masyarakat secara luas mengetahui keberadaan produk yanng dijual.

\section{F. Rencana Anggran Biaya (RAB)}

- Rencana Anggaran Biaya (RAB)

Tabel 4 RAB Bahan (Variable Cost)

\begin{tabular}{|c|c|c|c|c|c|}
\hline No & Nama & Satuan & Jumlah & $\begin{array}{c}\text { Harga Satuan } \\
\text { (Rp) }\end{array}$ & $\begin{array}{c}\text { Jumlah Harga } \\
\text { (Rp) }\end{array}$ \\
\hline 1. & Minyak goreng & Liter & 2 & Rp. 17.000 & Rp. 34.000 \\
\hline 2. & Sosis & toples & 1 & Rp. 21.000 & Rp. 21.000 \\
\hline 3. & Terigu & Bks & 1 & Rp. 10,000 & Rp. 10.000 \\
\hline 4. & Saus ABC (Sachet) & Bks & 2 & Rp. 6.000 & Rp. 12.000 \\
\hline 5. & Tepung Roti & Bks & 1 & Rp. 8.000 & Rp. 8.000 \\
\hline 6. & Mayonaise & Bks & 1 & Rp. 6.000 & Rp. 6.000 \\
\hline 7. & Telur & rak & 1 & Rp. 38.000 & Rp. 38.000 \\
\hline 8. & $\begin{array}{l}\text { Wortel, Ubi, daun } \\
\text { seledri \& daun } \\
\text { bawang }\end{array}$ & - & - & Rp. 10.000 & Rp. 10.000 \\
\hline \multicolumn{5}{|c|}{ Total } & Rp. 139.000 \\
\hline
\end{tabular}

Tabel 5 RAB Peralatan (Fix Cost)

\begin{tabular}{|l|c|l|l|c|c|}
\hline No & Nama & Satuan & Jumlah & $\begin{array}{c}\text { Harga Satuan } \\
(\mathrm{Rp})\end{array}$ & $\begin{array}{c}\text { Jumlah } \\
\text { harga (Rp) }\end{array}$ \\
\hline 1. & Mika GX3 & Pcs & 2 & Rp. 4.500 & Rp. 9.000 \\
\hline 2. & Isi staples & Pcs & 1 & Rp. 2.500 & Rp. 2.500 \\
\hline \multicolumn{5}{|c|}{ Total } & Rp 11.500 \\
\hline
\end{tabular}

\section{Perhitungan Biaya}

Total biaya yang dikeluarkan untuk memulai bisnis usaha risoles ini selama beberapa hari adalah : 
Total Anggaran Biaya :

\begin{tabular}{|c|c|}
\hline 1. Biaya Bahan & $=$ Rp. 139.000 \\
\hline 2. Biaya Peralatan & $=$ Rp. $11.500+$ \\
\hline Total & $=$ Rp. 151.500 \\
\hline Modal Awal & $=\mathrm{Rp} .150 .000$ \\
\hline
\end{tabular}

\section{Perhitungan penghasilan}

Pembuatan risoles ini dalam hitungan satu bulan, yang dimana usaha tersebut dijalankan pada saat mempunyai waktu luang atau diluar jam perkuliahan, menghasilkan penjualan :

- Minggu pertama = Rp. 45.000

- Minggu kedua = Rp. 55.000

- Minggu ketiga = Rp. 90.000

- Minggu keempat $=$ Rp. $150.000+$

Total $=\operatorname{Rp} 340.000$

III. Perhitungan Laba / Rugi

- Penghasilan Usaha $=$ Rp. 340.000

- Biaya yang dikeluarkan = Rp. 151.500

Jadi Laba / Rugi = Biaya Penghasilan-Biaya Pengeluaran

$=$ Rp. $340.000-151.500$

$=$ Rp. 188.500

Sisa Modal $\quad=(-R p .1 .500)$

$=$ Rp.188.500 - Rp.1.500

Laba Bersih $\quad=$ Rp. 187.000

Jumlah keseluruhan $=$ Rp. $187.000(1$ bulan $)$ 
HASIL DOKUMENTASI

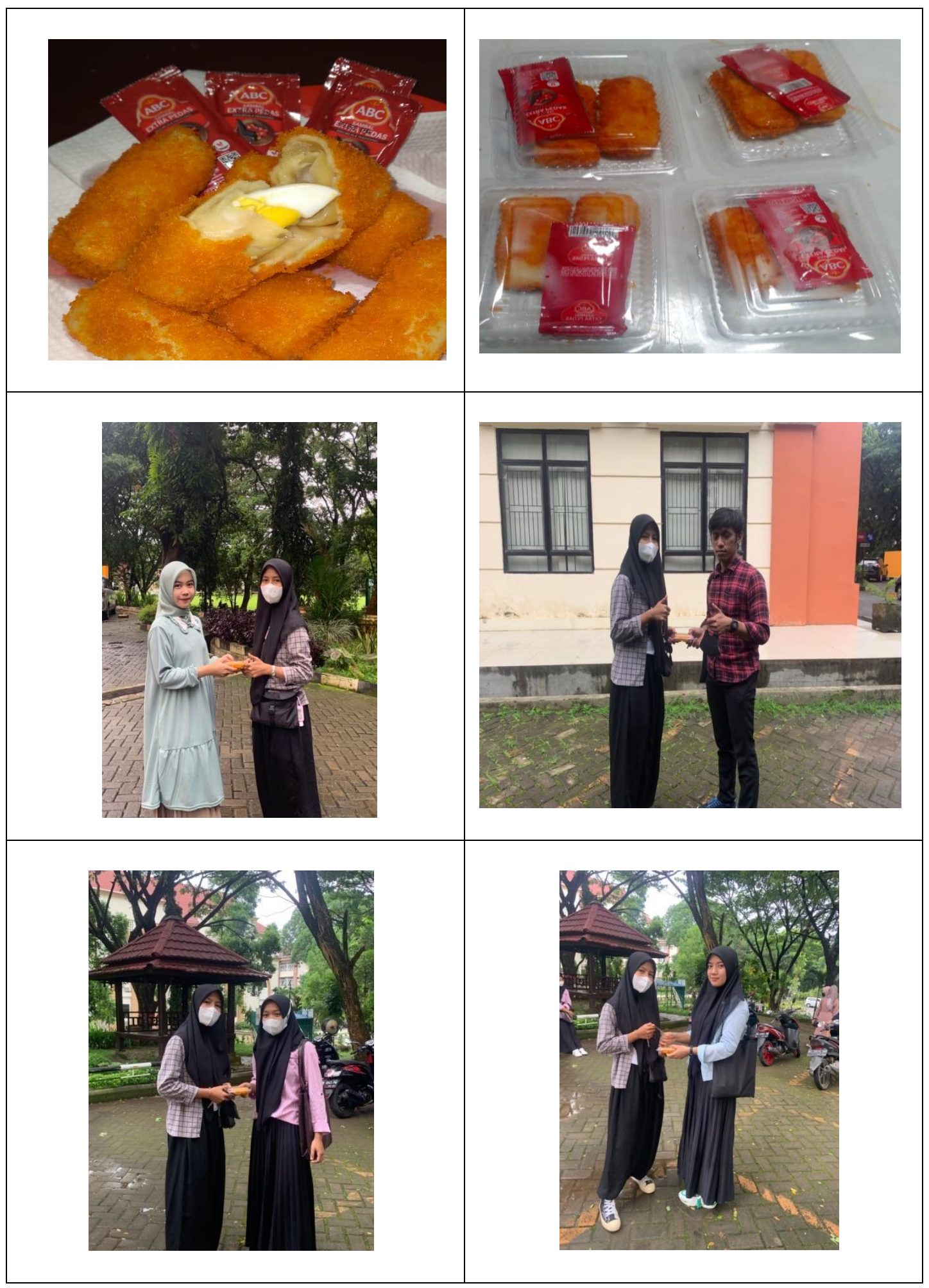




\section{BAB III}

\section{PENUTUP}

\section{A. Kesimpulan}

Pembuatan risoles ini sangat mudah dan modal usaha relatif kecil, cukup untuk dikantong mahasiswa. Alat proses produksi yang sedehana dan bahan baku yang mudah dicari serta keuntungan yang cukup menjanjikan untuk menjadikan bisnis risoles ini layak untuk dikembangkan. Usaha ini bisa akan maju terus-menerus jika dilakukan oleh orang-orang yang mempunyai kualitas dan bertanggung jawab dalam menjalankan pekerjaannya. Tetapi, usaha ini mungkin tidak akan langsung berkembang pesat dan dan pastinya akan mengalami pasang surut dalam suatu usaha.

Demikian bisnis yang kami jalani, dengan mempertimbangkan seluruh aspek-aspek usaha maupun peluang-peluang usaha yang mungkin dapt dimasukkan dalam dunia bisnis kedepannya. Dengan adanya bisnis ini diharapkan dapat memenuhi sebagian kebutuhan pasar atau konsumen. Apapun usahakan yang dijalankan harus mempertimbangkan segala macam pandangan atau peluang yang ada. Itulah kunci keberhasilan suatu usaha yang dijalankan dan merupakan tantangan bagi wirausahawan muda yang selalu berusaha untuk beradaptasi dengan persaingan bisnis sekarang yang sangat ketat.

\section{B. Saran}

Dengan mengucap syukur alhamdulillah pada Allah SWT penulis dapat menyelesaikan makalah ini dengan baik dan tentunya masih jauh dai harapan. Oleh karena itu penulis masih perlu saran ataupun kritik yang mebangun serta bimbingan, terutama dari dosen. Semoga makalah ini bermanfaat bagi pembaca dan penulis. 


\section{DAFTAR PUSTAKA}

http://www.indira.com/2015/06/resep-cara-membuat-risoles

http://www.resepcaramemasak/cara-membuat-resep-risoles-enakk/

https://www.kuliner/2013/05/resep-dan-cara-membuat-risol-enak

https://ayuwidiyanti/2014/11/usaha-kewirausahaan-risol. 